\title{
Meningkatkan Motivasi Belajar Menghadapi Ujian Nasional Melalui Metode Hipnoterapi
}

\author{
Ernawati \\ Institut Agama Islam Negeri Surakarta \\ ernawatikonseling@gmail.com \\ Galih Fajar Fadillah \\ Institut Agama Islam Negeri Surakarta \\ galihfajarf@gmail.com
}

\begin{abstract}
Abstrak
Salah satu inidikasi rendahnya motivasi belajar pada siswa dapat terlihat dari pelanggaran aturan. Tujuan penelitian ini untuk meningkatkan motivasi belajar siswa kelas IX jelang ujian nasional melalaui metode hipnoterapi. Jenis penelitian ini penelitian tindakan kelas (PTK) yang bersifat eksperimen partisipatif. Subjek penelitian adalah siswa kelas IX C SMP Muhammadiyah 1 Surakarta. Jumlah siswa sebanyak 32 siswa terdiri dari 14 laki-laki dan 18 perempuan. Hasil Peneilitian ini menunjukkan ada pengaruh metode hipnoterapi dalam meningkatkan motivasi belajar siswa kelas IX. Hasil pengukuran sebelum diberikan metode hipnoterapi perasaan yang dialami siswa menjelang ujian adalah terdapat 21 siswa merasa tidak semangat dan bingung, 5 siswa merasa takut, 4 siswa merasa belum siap dan hanya 2 siswa merasa senang dalam menghadapi ujian. Hasil setelah dberikan hipnoterapi 30 siswa merasa termotivasi, bersemangat dan merasa menyadari kesalahan diri serta 2 siswa merasa lebih percaya diri dan lebih berani hadapi ujian nasional.
\end{abstract}

Kata kunci: motivasi belajar, metode hipnoterapi

\begin{abstract}
One of the indications of low learning motivation in students can be seen from rules violations. The purpose of this study was to improve the learning motivation of IX graders ahead of
\end{abstract}




\section{Meningkatkan Motivasi Belajar Menghadapi Ujian Nasional ...}

the national exam through the hypnotherapy method. This type of research is classroom action research (CAR) which is a participatory experiment. The research subjects were class IX C Muhammadiyah Junior High School 1 Surakarta. The number of students was 32 students consisting of 14 men and 18 women. The results of this study indicate that there is an influence of the hypnotherapy method in increasing the learning motivation of class IX students. The results of the measurement before being given the hypnotherapy method, the feeling experienced by the students before the exam was that there were 21 students who felt discouraged and confused, 5 students felt scared, 4 students felt they were not ready and only 2 students felt happy in the test. The results after being given hypnotherapy are 30 students felt motivated, excited and felt aware of their own mistakes and 2 students felt more confident and more courageous in facing the national exam.

Keywords: learning motivation, hypnotherapy method

\section{A. Pendahuluan}

Salah satu inidikasi rendahnya motivasi belajar pada siswa dapat muncul dalam bentuk pelanggaran terhadap aturan, aturan yang berlaku dalam lingkungan keluarganya maupun aturan di lingkungan sekolah. Berdasarkan survey yang telah peneliti lakukan di sebuah SMP swasta di kota Solo pada bulan Juli 2011 -Juli 2012, menurut catatan guru BP/BK (Budi Pekerti/Bimbingan Konseling) dinyatakan bahwa dalam satu hari ada lebih dari 10 kasus pelanggaran yang dilakukan oleh SMP, baik itu pelanggaran berat sampai dengan ringan. Data yang peneliti peroleh menunjukkan pelanggaran tersebut beraneka macam seperti: merokok, bolos sekolah, berkelahi, memprovokasi terjadinya perkelahian, mencuri, tidak mengenakan atribut sekolah, tidak mengerjakan PR, , tidak mengikuti jadwal sholat di sekolah, tidak membawa alat sholat, tidak mengikuti upacara, terlambat, berbohong pada guru, meninggalkan buku di sekolah, tidak mengikuti pelajaran tertentu, berkata kotor pada teman dan guru, mencoret-coret tembok, pemalakan (meminta uang dengan paksa) dan lain sebagainya ( catatan lapangan, Juli 2012). 
Pelanggaran lain yang kerap di lakukan oleh siswa adalah masalah hubungan dengan lawan jenis. Dari Survei Kesehatan Reproduksi di Indonesia tahun 2003, diketahui 5 persen siswa pernah melakukan hubungan seks sebelum nikah. Lembar fakta yang diterbitkan oleh PKBI, United Nations Population Fund (UNFPA) dan Badan Koordinasi Keluarga Berencana Nasional (BKKBN) juga menyebutkan bahwa setiap tahun terdapat sekitar 15 juta siswa berusia 15-19 tahun melahirkan. Lembar fakta tersebut juga menyebutkan setiap tahun ada sekitar 2,3 juta kasus aborsi terjadi di Indonesia, dan 20 persennya dilakukan oleh siswa.(Erviani dalam Media HIV/AIDS dan Narkoba KULKUL Edisi 27, April 2007]

Motivasi tidak hanya menjadikan terlibat dalam kegiatan akademik, motivasi juga penting dalam menentukan seberapa jauh akan belajar dari suatu kegiatan pembelajaran atau seberapa jauh menyerap informasi yang disajikan kepada mereka. yang termotivasi untuk belajar sesuatu akan menggunakan proses kognitif yang lebih tinggi dalam mempelajari materi itu, sehingga itu akan meyerap dan mengendapkan materi itu dengan lebih baik. Salah satu tugas seorang guru adalah memotivasi nya.

Tugas penting guru adalah merencanakan bagaimana guru mendukung motivasi (Nur, 2001). Untuk itu sebagai seorang guru disamping menguasai materi, juga diharapkan dapat menetapkan dan melaksanakan penyajian materi yang sesuai kemampuan dan kesiapan anak, sehingga menghasilkan penguasaan materi yang optimal bagi. Dalam metode hipnoterapi siswa akan diberikan perlakuan dengan cara merilekskan seluruh anggota badan seperti orang sedang dalam posisi tidur namun masih dapat mendengar suara, sehingga dalam posisi rileks tersebut akan diberikan sugesti positif untuk memberikan kesadaran pada diri siswa sehingga akan dapat meningkatkan motivasi belajarnya.

Jenis penelitian ini adalah penelitian tindakan kelas(PTK) yang bersifat eksperimen, partisipatif. bertujuan untuk melakukan perbaikan -perbaikan terhadap sistim, cara kerja, proses, isi, dan kompetensi atau situasi pembelajaran. Lokasi Penelitian dilaksanakan di SMP Muhammadiyah 1 Surakarta. Jl Flores 1 Surakarta. Subjek penelitian adalah siswa kelas IX C dengan jumlah siswa sebanyak 32 siswa. Terdiri dari 14 siswa laki-laki dan 18 siswa 
perempuan. Penelitian ini dilaksanakan pada semester satu bulan November 2012 dan semester 2 bulan Maret 2013 tahun pelajaran 2012/2013.

Teknik pengumpulan data pada penelitian tindakan kelas ini mengunakan teknik observasi untuk mengamati perkembangan perilaku siswa selama pelaksaaan tindakan penelitian, wawancara untuk mengetahui sejauh mana motivasi siswa dan angket terbuka. Sedangkan alat pengumpulan data utama melalui angket terbuka, disamping itu juga menggunakan checklist untuk data observasi dan pedoman wawancara untuk triangulasi sumber dan metode.

\section{B. Pembahasan}

\section{Metode Hipnoterapi}

Menurut Indramajid (2013) beberapa definisi tentang hipnoterapi yang pernah diungkapnya diantaranya: Hipnoterapi adalah suatu kondisi yang menyerupai tidur yang dapat secara sengaja dilakukan kepada seseorang, di mana seseorang yang dihipnoterapi bisa menjawab pertanyaan yang diajukan, serta lebih mudah menerima sugesti.

Dapat pula dikatakan Hipnoterapi adalah praktek mempengaruhi orang lain agar mengikuti apa yang diperintahkan oleh ahli hipnoterapi. Hipnoterapi ini dapat digambarkan suatu kondisi pikiran yang terpusat sehingga tingkat sugestibilitas Daya terima saran) meningkat sangat tinggi. Hipnoterapi adalah seni komunikasi untuk mempengaruhi seseorang sehingga mengubah tingkat kesadarannya, yang dicapai dengan cara menurunkan gelombang otak dari Beta menjadi Alpha/Theta. Hipnoterapi adalah seni eksplorasi alam bawah sadar.

Dari pengertian di atas dapat disimpulkan bahwa hipnoterapi merupakan suatu pendekatan atau terapi yang diberikan kepada seseorang dengan cara menyerupai tidur yang dapat secara sengaja dilakukan, di mana seseorang yang dihipnoterapi bisa menjawab pertanyaan yang diajukan, serta lebih mudah menerima sugesti.

\section{Faktor-faktor yang mempengaruhi Hipnoterapi}

Menurut Indramajid (2013) Faktor-faktor yang mempengaruhi Hipnoterapi diantaranya 1) Faktor internal atau dari dalam individu yang di hipnoterapi. Seperti kecemasan, ketakutan 
atau kondisi psikis lainnya. 2) Faktor eksternal atau dari luar seperti sarana dan prasarana penunjang saat hipnoterapi diberikan. Menurut Falah (2012) hipnoterapi dipengaruhi yang utama dari faktor orang yang di hipnoterapi, artinya ketika di hipnoterapi ia menerima perlakuan atau sugesti yang diberikan ataukah menolak.

Dari faktor-faktor diatas dapat disimpulkan bahwa faktorfakor yang mempengaruhi hipnoterapi adalah faktor internal dan faktor eksternal. Motivasi dapat dikatakan sebagai proses yang memberi semangat, arah, dan kegigihan perilaku. Artinya, perilaku yang termotivasi adalah perilaku yang penuh energi, terarah, dan bertahan lama (Santrock, 2008).

Soemanto (2006) merumuskan bahwa motivasi belajar merupakan faktor psikis yang bersifat non intelektual yang berperan dalam menimbulkan gairah belajar serta perasaan senang dan bersemangat untuk belajar. Suryabrata (2008) menyatakan bahwa motivasi belajar adalah kondisi psikologis yang mendorong seseorang untuk belajar agar mendapatkan kepandaian.

Menurut Sardiman (2011) motivasi belajar merupakan keseluruhan daya penggerak psikis dalam diri yang menimbulkan kegiatan belajar. Menjamin kelangsungan belajar dan tercapai tujuan yang dikehendaki. Hal ini menunjukkan bahwa yang memiliki motivasi belajar akan dapat meluangkan waktu belajar lebih banyak dan lebih tekun daripada mereka yang kurang memiliki atau sama sekali tidak mempunyai motivasi belajar.

Dari uraian di atas dapat disimpulkan bahwa motivasi belajar adalah kondisi psikologis yang merupakan swadaya penggerak dalam diri seseorang untuk memulai kegiatan atau aktivitas belajar atas kemauannya sendiri atau minat individu dan menyelesaikan tugas tepat waktu, sehingga tujuan yang dikehendaki oleh subyek belajar itu dapat tercapai.

\section{Faktor - Faktor Yang Mempengaruhi Motivasi Belajar}

Sabur (Suryabrata, 2008) menjelaskan bahwa motivasi berdasarkan faktor-faktor yang mempengaruhinya dibagi menjadi dua yaitu, motivasi intrinsik dan motivasi ekstrinsik. Motivasi intrinsik adalah motivasi yang dapat bekerja tanpa dipengaruhi oleh faktor-faktor dari luar, dalam diri individu memang sudah terdapat dorongan untuk melakukan sesuatu. Sedangkan motivasi ekstrinsik 
adalah motivasi yang dapat bekerja karena dipengaruhi oleh faktorfaktor dari luar seperti situasi lingkungan, dan sebagainya.

Syah (2010) Menjabarkan bahwa secara global faktor yang mempengaruhi motivasi belajar dapat dibedakan menjadi tiga macam, yaitu : a) Faktor internal. Keadaan yang berasal dari dalam diri seperti keadaaan jasmani, rohani , kecerdasan, emosi, dan sikap, b) Faktor eksternal. Keadaan di luar diri seperti kondisi lingkungan disekitar. Dengan berinteraksi dengan lingkungan disekitar menimbulkan terjadinya penyesuian diri dengan lingkungan disekitarnya, c) Faktor pendekatan belajar. Pemahaman ini mengenai jenis upaya jenis upaya belajar yang meliputi strategi dan metode yang digunakan untuk melakukan kegiatan pembelajaran.

Sutiman (Suryabrata, 2008) menjelaskan tentang faktor faktor mengenai motivasi belajar yaitu : a) Latar belakang pribadi. Penjelasan ini meliputi jenis kelamin, tinggi badan, cacat, kesulitan berbicara, kemauan berbicara, b) Latar belakang keluarga. Penjelasan ini meliputi keadaan keluarga, jumlah saudara kandung, anak yang keberapa, dan jumlah kakak yang sudah bekerja.

Pendapat yang lebih tajam mengenai motivasi belajar dijelaskan pula oleh Syah (2010) bahwa terdapat empat faktor yang mempengaruhi motivasi belajar, yaitu : a) Kebudayaan. Jika suatu budaya memiliki nilai yang tinggi terhadap pendidikan, maka masyarakat budaya tersebut akan banyak mendorong para untuk belajar keras agar menjadi orang yang benar - benar terdidik. Masyarakat ini akan lebih menghargai seseorang karena usaha yang keras daripada karena sesuatu yang lebih bersifat keberuntungan, b) Lingkungan keluarga. Keluarga memberikan pengaruh primer terhadap motivasi belajar seseorang. Dengan dukungan dari orang tua menimbulkan interaksi sosial antara anak dengan keluarga, c) Lingkungan sekolah. Dilingkungan ini bukan hanya peran guru yang penting untuk memotivasi belajar, namun juga dibutuhkan peran teman sebaya yang berada dilingkungan sekolah untuk mendukung motivasi belajar. Hal ini disebabkan karena dengan adanya hubungan yang baik antara dengan teman kelompoknya, maka secara tidak langsung akan membuat tersebut merasa berharga dan berarti dimata teman - temannya, sehingga akan memacu semangat untuk 
belajar, d) Keinginan itu sendiri untuk belajar. Pada prinsipnya, motivasi belajar harus dibangun dari diri sendiri.

Berdasarkan uraian yang telah dipaparkan di atas, dapat disimpulkan bahwa motivasi belajar sangat dipengaruhi oleh faktor motivasi internal seperti keadaan jasmani dan rohani, keinginan itu sendiri untuk belajar, serta pendekatan belajar yang digunakan selama melakukan kegiatan belajar. Dilain pihak, terdapat pula faktor motivasi eksternal yang mempengaruhi motivasi belajar, antara lain kebudayaan, latar belakangan keluarga, kondisi lingkungan disekitar, dan lingkungan sekolah.

\section{Hasil Dan Pembahasan}

Metode hipnoterapi merupakan sebuah metode yang diberikan oleh seorang guru yang telah terlatih dalam memberikan hipnoterapi terutama di bidang pendidikan. Gambaran alur pemberian metode hipnoterapi dapat di ilustrasikan sebagai berikut :

Untuk satu kelas dengan jumlah siswa 25-35 siswa seorang guru membutuhkan dua observer yang akan membantu proses pemberian metode hipnoterapi ini. Dalam penelitian ini jumlah siswa ada 32 siswa sehingga membetuhkan 2 orang observer yang membantu proses pelaksanaan hipnoterapi. Pelaksanaan penelitian di awalai dengan memberikan angket terbuka kepada para siswa tentang apa yang mereka rasakan menjelang ujian nasional, siswa boleh menuliskan apapun yang mereka rasakan ketika sudah kelas IX dan beberapa bulan ke depan akan menghadapi ujian nasional. Setelah angket terbuka dikumpulkan siswa akan mendapatkan materi terlebih dahulu sebelum proses hipnoterapi dilaksanakan. Guru memberikan materi tentang tips-tips dalam menghadapi ujian nasioanl kepada para siswa berdurasi kurang lebih 45 menit. Itu di sebut sebagai sessi pertama. Sessi ke dua adalah pelaksanaan hipnoterapi.

Pelaksanaan hipnoterapi dalam bidang pendidikan membutuhkan waktu kurang lebih 60 menit. Pelaksanaan Hipnoterapi dibagi menjadi beberapa bagian yaitu bagian pertama pembukaan, bagian kedau inti hipnoterapi dan pemberian sugesti positif dan bagian tiga penutup. Siswa terlebih dikondisikan dalam posisi tiduran dengan posisi tangan dikana kiri badan, kedua kaki diluruskan dan tidak bertumpuk serta mata dipejamkan untuk 


\section{Meningkatkan Motivasi Belajar Menghadapi Ujian Nasional ...}

membantu konsentrasi. Tahap pertama pembukaan Guru memberikan pengertian terlebih dahulu bahwa pelaksanan hipnoterapi pendidikan ini untuk kebaikan para siswa, untuk membantu siswa lebih konsentrasi, lebih termotivasi terutama dalam menghadapi ujian nasional. Siswa diminta berkonstrasi untuk mengikuti alur cerita yang akan di hantarkan oleh guru. Kata-kata untuk mengawali bisa dengan kata "mari bersama-sama kita membaca basmallah agar hipnoterapi yang akan kita jalani ke depan memberikan manfaat kepada kita terutama dalam memotivasi diri menghadapi ujian nasional”. Lalu selanjutnya siswa diminta untuk tarik nafas perlahan lahan sambil guru berkata " ijinkan dan niatkan setiap tarikan nafas ini akan membantu kita merasa lebih rileks,lebih nyaman dari waktu-waktu sebelumnya". Ini disebut tahap pembukaan. Guru memastikan siswa dalam kondisi rileks dan nyaman saat hiponoterpai tersebut berjalan.

Selanjutnya adalah tahap memasuki alam bawah sadar para siswa. Masih dalam posisi tiduran dengan mata terpejam tersebut, guru meneruskan alur cerita dalam pelaksanaan hipnoterapi. Siswa diminta untuk membayangkan tentang jerih payah orang tua mereka dalam bekerja dan mendampingi anak-anak nya agar dapat bersekolah. Tahap ini masuk dalam yahp inti hipnoterapi. Dalam tahap ini sisw disentuh rasa bersalah terhadap kesalahan baik terhadap diri sendiri, orang tua, guru dna teman. Ditumbuhkan pula rasa tanggung jawabnya, rasa kasih sayang terhadap orang tua dan terakhir di tumbuhkan rasa motivasi dalam menghadapi ujian nasional sebagaai bukti balas budi akan jerih payah orang tua dan guru di sekolah.

Selanjutnya siswa di berikan sugesti posistif berupa kata-lata motivasi bagi dirinya, kata-kata motivasi tersebut diberikan dalam kondisi siswa masih terpejam. Pemberian sugesti positif menurut beberapa ahli psikologi akan memberikan dampak positif pada siswa untuk menyiapkan mentalnya terutama dalam menghadapi ujian nasional. Pemberian sugesti dalam kondisi siswa masih berada dalam alam bawah sadarnya juga akan menumbuhkan motivasi dari dalam dirinya sendiri. Sugesti positif tersebut dapat disampaikan oleh guru dengan kata-kata sebagai berikut "mulai detik ini dan seterusnya aku berjanji akan memperbaiki ibadahku dan aku akan mengatur waktu 
ku", " mulai detik ini dan seterusnya aku berjanji akan memperbaiki belajarku dan aku yakin kau kan bisa mengadapi ujian nasional dengan penuh percaya diri".

Tahap terakhir adalah tahap penutup. Pada tahap ini guru harus mampu memastikan bahwa semua siswa sudah tersugesti positif. Bila sudah maka perlahan-lahan siswa di tenangkan kembali dari kondisi masih tiduran, dan dibangunkan secara perlahan-lahan, dalam yahap ini rangkain hipnoterapi telah usai. Setelah itu siswa diminat untuk saling mmeaafkan dan saling mendaoakan dengan teman-teman nya dan meminta dao restu pada guru dna orang tua di rumah.

Sebelum memulai pelatihan, peneliti menyebarkan angket terbuka dengan pertanyaan apa yang siswa rasakan menjelang ujian nasional?. Pertanyaan tersebut diberikan kepada seluruh siswa yang berjumlah 32. Hasil jawaban mereka peneliti sajikan dalam tabel 2 seperti di bawah ini:

\begin{tabular}{|c|c|c|c|c|c|}
\hline \multirow[b]{2}{*}{ No } & \multirow[b]{2}{*}{ Nama Siswa } & \multicolumn{4}{|c|}{$\begin{array}{c}\text { Perasaan Yang Di Rasakan Siswa } \\
\text { Menjelang Ujian }\end{array}$} \\
\hline & & $\begin{array}{c}\text { Tdk } \\
\text { Semangat } \\
\text { Dan } \\
\text { bingung }\end{array}$ & Takut & $\begin{array}{c}\text { Belum } \\
\text { Siap }\end{array}$ & Senang \\
\hline 1 & Agung Widi & & V & & \\
\hline 2 & Arvin Febriyono & $\mathrm{V}$ & & & \\
\hline 3 & Ayu Fadliyah & $\mathrm{V}$ & $\mathrm{V}$ & & $\mathrm{V}$ \\
\hline 4 & Anindya Icha & $\mathrm{V}$ & & & \\
\hline 5 & Aulia Dwita & V & V & & \\
\hline 6 & Anditya Pamungkas & $\mathrm{V}$ & & & \\
\hline 7 & Agung Nugroho & $\mathrm{V}$ & & & \\
\hline 8 & Andhika Anjas R & & & V & \\
\hline 9 & Bintang Ramadhan & V & & $\mathrm{V}$ & \\
\hline 10 & Bicky Zakia & V & & & \\
\hline 11 & Debby Novitasari & $\mathrm{V}$ & $\mathrm{V}$ & & \\
\hline 12 & Dinar Ayu N & $\mathrm{V}$ & & & \\
\hline 13 & Dhima Wahyu & $\mathrm{V}$ & & $\mathrm{V}$ & \\
\hline 14 & David Permana & V & & & \\
\hline
\end{tabular}


Meningkatkan Motivasi Belajar Menghadapi Ujian Nasional ...

\begin{tabular}{|c|c|c|c|c|c|}
\hline 15 & Dwi Nur Oktaviani & $\mathrm{V}$ & & & \\
\hline 16 & Irwan Yhudhantoro & & & & \\
\hline 17 & Indah Khairunnisa & & & & \\
\hline 18 & Ilham Fatimah & V & & & \\
\hline 19 & Krishna Putra & $\mathrm{V}$ & & $\mathrm{V}$ & \\
\hline 20 & Linda R M & $\mathrm{V}$ & V & & \\
\hline 21 & Marhaban Arya & $\mathrm{V}$ & & & V \\
\hline 22 & Miftakh Nur Aini & & & & \\
\hline 23 & Muh.Naufal & V & & & \\
\hline 24 & Putri Rizal & & & & \\
\hline 25 & Reno Latief & $\mathrm{V}$ & & & \\
\hline 26 & Rullyanda Nur & V & & & \\
\hline 27 & Rianda Diffa & & & & \\
\hline 28 & Sarah Olivia & $\mathrm{V}$ & & & \\
\hline 29 & Shafa Salma & & & & \\
\hline 30 & Sinta Febriani & & $\mathrm{V}$ & & \\
\hline 31 & Troy Corser & & & & \\
\hline 32 & Vivid Oktania & & $\mathrm{V}$ & & \\
\hline & JUMLAH & 21 & 5 & 4 & 2 \\
\hline
\end{tabular}

Dari tabel di atas diketahui bahwa perasaan yang dialami siswa saat menjelang ujian adalah terdapat 21 siswa merasa tidak semangat dan bingung, 5 siswa merasa takut, 4 siswa merasa belum siap dan hanya 1 siswa merasa senang dalam menghadapi ujian.

Hal tersebut sesuai yang di sampaikan oleh Syah (2010) bahwa terdapat empat faktor yang mempengaruhi motivasi belajar, yaitu :

a. Kebudayaan. Jika suatu budaya memiliki nilai yang tinggi terhadap pendidikan, maka masyarakat budaya tersebut akan banyak mendorong para untuk belajar keras agar menjadi orang yang benar - benar terdidik. Masyarakat ini akan lebih menghargai seseorang karena usaha yang keras daripada karena sesuatu yang lebih bersifat keberuntungan.

b. Lingkungan keluarga. Keluarga memberikan pengaruh primer terhadap motivasi belajar seseorang. Dengan dukungan dari orang tua menimbulkan interaksi sosial antara anak dengan keluarga 
c. Lingkungan sekolah. Dilingkungan ini bukan hanya peran guru yang penting untuk memotivasi belajar, namun juga dibutuhkan peran teman sebaya yang berada dilingkungan sekolah untuk mendukung motivasi belajar. Hal ini disebabkan karena dengan adanya hubungan yang baik antara dengan teman kelompoknya, maka secara tidak langsung akan membuat tersebut merasa berharga dan berarti dimata teman - temannya, sehingga akan memacu semangat a untuk belajar.

d. Keinginan itu sendiri untuk belajar. Pada prinsipnya, motivasi belajar harus dibangun dari diri sendiri.

Jika hal tersebut tidak dikondisikan dengan baik, maka motivasi belajar siswa akan terus menurun. Tentunya dipelukan metode untuk meningkatkan motivasi belajar siswa terutama saat menjelang ujian nasional. Metode hipnoterapi menjadi salah satu alternatif untuk meningkatkan motivasi siswa menjelang ujian nasional.

Setelah diberikan perlakuan dengan menggunakan metode hipnoterapi, selanjutnya diadakan penyebaran angket terbuka dengan pertanyaan "Apa yang dirasakan oleh seluruh siswa setelah mendapatlan perlakuan dengan metode hipnoterapi?, Beragam jawaban siswa tersebut dapat di gambaran dalam tabel 3 berikut:

\begin{tabular}{llcc}
\hline & & \multicolumn{2}{c}{$\begin{array}{c}\text { Perasaan Yang Di Rasakan Siswa } \\
\text { Setelah Hipnoterapi }\end{array}$} \\
\cline { 3 - 4 } No & Nama Siswa & $\begin{array}{c}\text { Lebih } \\
\text { Semangat/Termotivasi } \\
\text { dan menyadari } \\
\text { kesalahan diri }\end{array}$ & $\begin{array}{c}\text { Percaya Diri } \\
\text { Dan merasa } \\
\text { lebih berani }\end{array}$ \\
\hline 1 & Agung Widi & & $\mathrm{V}$ \\
\hline 2 & Arvin Febriyono & $\mathrm{V}$ & \\
\hline 3 & Ayu Fadliyah & $\mathrm{V}$ & \\
\hline 4 & Anindya Icha & $\mathrm{V}$ & \\
\hline 5 & Aulia Dwita & $\mathrm{V}$ & $\mathrm{V}$ \\
\hline 6 & Anditya & $\mathrm{V}$ & \\
\hline 7 & Pamungkas & Agung Nugroho & $\mathrm{V}$ \\
\hline 8 & Andhika Anjas $\mathrm{R}$ & $\mathrm{V}$ & \\
\hline
\end{tabular}


Meningkatkan Motivasi Belajar Menghadapi Ujian Nasional ...

\begin{tabular}{lll}
\hline 9 & $\begin{array}{l}\text { Bintang } \\
\text { Ramadhan }\end{array}$ & $\mathrm{V}$ \\
\hline 10 & Bicky Zakia & $\mathrm{V}$ \\
\hline 11 & Debby Novitasari & $\mathrm{V}$ \\
\hline 12 & Dinar Ayu N & $\mathrm{V}$ \\
\hline 13 & Dhima Wahyu & $\mathrm{V}$ \\
\hline 14 & David Permana & $\mathrm{V}$ \\
\hline 15 & Dwi Nur & $\mathrm{V}$ \\
& Oktaviani & \\
\hline
\end{tabular}

\begin{tabular}{ll}
\hline 16 & Irwan \\
& Yhudhantoro \\
\hline 17 & Indah \\
& Khairunnisa
\end{tabular}

\begin{tabular}{lll}
\hline 18 & Ilham Fatimah & V \\
\hline 19 & Krishna Putra & V \\
\hline 20 & Linda R M & V
\end{tabular}

21 Marhaban Arya

\begin{tabular}{llc}
\hline 22 & Miftakh Nur Aini & V \\
\hline 23 & Muh.Naufal & V \\
\hline 24 & Putri Rizal & V \\
\hline
\end{tabular}

25 Reno Latief $\quad \mathrm{V}$

\begin{tabular}{lll}
\hline 26 & Rullyanda Nur & V \\
\hline 27 & Rianda Diffa & V
\end{tabular}

28 Sarah Olivia $\mathrm{V}$

\begin{tabular}{lll}
\hline 29 & Shafa Salma & V \\
\hline 30 & Sinta Febriani & V
\end{tabular}

\begin{tabular}{lll}
\hline 31 & Troy Corser & V \\
\hline 32 & Vivid Oktania & V
\end{tabular}

\begin{tabular}{ccc}
\hline JUMLAH & $\mathbf{3 0}$ & $\mathbf{2}$ \\
\hline Dari tabel di atas dapat kita lihat bersama perbedaan
\end{tabular}

sebelum dan sesudah pemberian metode hipnoterapi dalam meningkatkan motivasi belajar siswa menjelang ujain nasional. Hal tersebut mendukung pendapat dari Santrock, (2008) bahwa faktorfakor yang mempengaruhi hipnoterapi adalah faktor internal dan faktor eksternal. Motivasi dapat dikatakan sebagai proses yang memberi semangat, arah, dan kegigihan perilaku. Artinya, perilaku 
yang termotivasi adalah perilaku yang penuh energi, terarah, dan bertahan lama (Santrock, 2008). Metode hipnoterapi terbukti mampu memunculkan motivasi belajart internal pada siswa.

Soemanto (2006) menambahkan bahwa motivasi belajar merupakan faktor psikis yang bersifat non intelektual yang berperan dalam menimbulkan gairah belajar serta perasaan senang dan bersemangat untuk belajar. Suryabrata (2008) menyatakan bahwa motivasi belajar adalah kondisi psikologis yang mendorong seseorang untuk belajar agar mendapatkan kepandaian. Dengan pendapat para ahli tersebut dapat dikatakan pemberian metode hipnoterapi memberikan dampak positif dalam meningkatkan motivasi belajar siswa.

\section{Simpulan}

Hasil Peneilitian ini menunjukkan ada pengaruh metode hipnoterapi dalam meningkatkan motivasi belajar siswa kelas IX. Hasil pengukuran sebelum diberikan perlakuan perasaan yang dialami siswa saat menjelang ujian adalah terdapat 21 siswa merasa tidak semangat dan bingung, 5 siswa merasa takut, 4 siswa merasa belum siap dan hanya 2 siswa merasa senang dalam menghadapi ujian. Hasil setelah dberikan perlakuan sebagai berikut 30 siswa merasa termotivasi dan bersemangat dan merasa menyadari kesalahan diri dan 2 siswa merasa lebih percaya diri merasa lebih berani hadapi ujian nasional

Motivasi belajar siswa bisa tumbuh secara internal ataupun karena faktor ekternal. Motivasi belajar dengan metode hipnoterapi merupakan alternatif solusi yang tepat dalam menanggani permasalahan rendah motivasi belajar pada siswa terutama menjelang ujian nasional. Kiranya metode hipnoterapi ini bisa menjadi keterampilan yang perlu diberikan oleh berbagai guru mata pelajaran terutama guru bimbingan kosneling diberbagai sekolah di seluruh Indonesia. 
Meningkatkan Motivasi Belajar Menghadapi Ujian Nasional ...

\section{Daftar Pustaka}

Departemen Pendidikan Dan Kebudayaan. 1990. Kamus Besar Bahasa Indonesia. Jakarta: Balai Pustaka

Dimyati dan Mujiono. 2002. Belajar dan Pembelajaran. Jakarta: Rineka Cipta

Efrida, SR. 2009. Persepsi Cara Mengajar Guru Dengan Motivasi Belajar SMP Katolik Yohanes Gabriel Blitar. Diambil dari fpsikologi@wisnuwardhana.ac.id. Diakses tanggal 20 Februari 2011

Erviani dalam Media HIV/AIDS dan Narkoba KULKUL Edisi 27, April 2007]

Lestari, Sri. 2003. Meningkatkan Motivasi Belajar Kelas V SD negeri Plamongan Sari 01 Semarang Melalui Tutor Teman Sebaya Tahun Pelajaran 2002 / 2003. Skripsi. Universitas Negeri Semarang

Sardiman, A.M. 2011. Interaksi Dan Motivasi Belajar Mengajar. Jakarta : PT Raja Grafindo Persada.

Santrock, J.W. 2008. Perkembangan Remaja. Jakarta : Erlangga

Sarwono, S.W. 2010. Pengantar Psikologi Umum. Jakarta : Rajawali.

Soemanto, W. 2006. Psikologi Pendidikan (Landasan Kerja Pemimpin Pendidikan). Jakarta : Rajawali.

Solopos, 25 Febuari 2012. 600 Pelajar Diduga Terlibat Geng. Hal I dan III

Suhartono, 2005. Penyelenggaraan Program Kelas Unggulan di Sekolah Dasar.

Jurnal. Pendidikan, Vol.6, No.2, September 2005, 113-132

Suryabrata, S. 2005. Psikologi Pendidikan. Jakarta. Rajawali Pers. 2008. Metodologi Penelitian. Jakarta : Rajawali.

Syah, M. 2010. Psikologi Belajar. Jakarta : PT Raja Grafindo Persada.

Catatan lapangan,2012

Wawancara RF, Juli 2012

Wawancara JR,Juli 2012 